Gender and the Science of Difference 
Studies in Modern Science, Technology, and the Environment

Edited by Mark A. Largent

The increasing importance of science over the past 150 years-and with it the increasing social, political, and economic authority vested in scientists and engineers-established both scientific research and technological innovations as vital components of modern culture. Studies in Modern Science, Technology, and the Environment is a collection of books that focuses on humanistic and social science inquiries into the social and political implications of science and technology and their impacts on communities, environments, and cultural movements worldwide.

Mark R. Finlay, Growing American Rubber: Strategic Plants and the Politics of National Security

Jill A. Fisher, ed., Gender and the Science of Difference: Cultural Politics of Contemporary Science and Medicine

Gordon Patterson, The Mosquito Crusades: A History of the American Anti-Mosquito Movement from the Reed Commission to the First Earth Day

Jeremy Vetter, Knowing Global Environments: New Historical Perspectives on the Field Sciences 


\title{
Gender and the Science of Difference
}

\section{Cultural Politics of Contemporary Science and Medicine}

\author{
EDITED BY \\ JILL A. FISHER
}

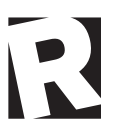

RUTGERS UNIVERSITY PRESS 


\section{LIBRARY OF CONGRESS CATALOGING-IN-PUBLICATION DATA}

Gender and the science of difference : cultural politics of contemporary science and medicine / edited by Jill A. Fisher.

p. cm. - (Studies in modern science, technology, and the environment) Includes bibliographical references and index.

ISBN 978-O-8I35-5046-6 (hardcover : alk. paper) - ISBN 978-O-8I35-5047-3 (pbk. : alk. paper)

I. Sex differences. 2. Sex differences-Political aspects. 3. Sex (Biology)-Social aspects. 4. Human biology-Philosophy. I. Fisher, Jill A., I976QP8I.5.G46 2OII

$6 \mathrm{I} 2.6-\mathrm{dc} 22$ 2010040714

A British Cataloging-in-Publication record for this book is available from the British Library.

This collection copyright (C) 20II by Rutgers, The State University

Individual chapters copyright (C) 20II in the names of their authors

All rights reserved

No part of this book may be reproduced or utilized in any form or by any means, electronic or mechanical, or by any information storage and retrieval system, without written permission from the publisher. Please contact Rutgers University Press, IOO

Joyce Kilmer Avenue, Piscataway, NJ 08854-8099. The only exception to this prohibition is "fair use" as defined by U.S. copyright law.

Visit our Web site: http://rutgerspress.rutgers.edu Manufactured in the United States of America 